inOedia $\quad \begin{aligned} & \text { InMedia } \\ & \text { The French Journal of Media Studies }\end{aligned}$

$1 \mid 2012$

Global Film and Television Industries Today

\title{
Lights! Tystnad! Azione! Practices, Sites and Careers in European Film Production
}

7-8 April 2011, Department for Cinema Studies, Stockholm University, Stockholm

Melis Behlil

\section{CpenEdition}

\section{Journals}

Édition électronique

URL : http://journals.openedition.org/inmedia/233

DOI : 10.4000/inmedia.233

ISSN : 2259-4728

Éditeur

Center for Research on the English-Speaking World (CREW)

Référence électronique

Melis Behlil, «Lights! Tystnad! Azione! Practices, Sites and Careers in European Film Production », InMedia [En ligne], 1 | 2012, mis en ligne le 16 mars 2012, consulté le 08 septembre 2020. URL : http:// journals.openedition.org/inmedia/233; DOI : https://doi.org/10.4000/inmedia.233

Ce document a été généré automatiquement le 8 septembre 2020

(c) InMedia 


\title{
Lights! Tystnad! Azione! Practices, Sites and Careers in European Film Production
}

\author{
7-8 April 2011, Department for Cinema Studies, Stockholm University, \\ Stockholm
}

Melis Behlil

\section{NOTE DE L'ÉDITEUR}

Conference organized by Patrick Vonderau, Petr Szczepanik and Dorota Ostrowska

1 Within the last decade, Production Studies has emerged as a new field of inquiry within cinema and media studies, going beyond traditional examinations of authorship, industry structure, or active audiences. A conference generously hosted by Stockholm University, and organized by Patrick Vonderau in collaboration with Petr Szczepanik and Dorota Ostrowska in April 2011, proclaimed itself as "the first European intervention into this burgeoning field of study." Indeed, contributions to the field have almost exclusively been made by US American scholars so far, and to quote the organizers, explorations within European contexts "either have been confined to individual projects emanating from disciplines not specializing in film and media studies, such as organizational sociology, management studies, cultural economics, and cultural anthropology, or they have focused on particular fields, such as screenwriting or animation." Thus, perhaps predictably, but also in an all-embracing manner that is seldom encountered at other film studies conferences, the Stockholm conference entitled "Lights! Tystnad! Azione! Practices, Sites and Careers in European Film Production" brought together academics from different fields.

There were many film scholars, mainly from Humanities faculties across Europe and the US, but also researchers from a number of Business Schools working mostly in Organizational Studies. During the opening speeches, Patrick Vonderau of Stockholm 
University remarked that one of the main aims of the event was "to make Humanities dialogue with Social Sciences." Said dialogue was indeed established, giving a chance to scholars from both fields to peek into realms they are not familiar with. It was a small conference with clearly defined goals; consequently most attendees were more concerned with theories and methodologies than at most other conferences. This proved to be useful, as those in the field of Production Studies are still grappling with terminologies and concepts. Dorota Ostrowska's presentation, "Filming Emotions," drew attention to these questions, highlighting the importance of materiality and raising the question of suitable methodologies.

Nearly all papers addressed the question of methodology in one way or another and three approaches appeared throughout. Several papers largely documented historical research based on archival material. The very first panel of the conference brought together Daniel Steinhart's research on Hollywood studios' runaway productions in Europe in 1960s, Petr Szczepanik's presentation on the function of the dramaturge in Czechoslovakian cinema and Alex Zons's work on Hollywood's talent agents as major actors within production culture. Malin Wahlberg later presented work on archival material: her study looked at a transnational collaboration between Sweden and the US for a series of documentaries about Sweden on American Public Television in the 1960s.

Participant observation was another frequently employed approach, more so by scholars with a background in Social Sciences. Anna Zoellner's study of documentary production for television in Germany and the UK and Dimitrinka Stoyanova's research in British independent production companies were clear examples of this. These presenters had also conducted interviews, which emerged as the preferred methodology across the board - for example Chris Mathieu's study, which involved 57 interviews with the Danish cinema 'élite.' Interviews do provide a remarkable insight into the production process. But at the same time, one needs to be aware of their reflexive nature: it is a community dealing in the business of telling stories, their own stories. In one of the pioneering works in the field, Production Culture: Industrial Reflexivity and Critical Practice in Film and Television, John Caldwell of UCLA analyzes not only the act of production, but also the narratives and rituals through which media laborers in varying positions make sense of their work.

5 John Caldwell was also present at the Stockholm conference to deliver the keynote lecture. In his talk entitled "Distributing and Managing Production Knowledge: How Culture Leaks out of Production," Caldwell suggested the messy discipline of Production Studies be seen as a toolkit. His speech was a valuable reminder of why Production Studies is performed largely within the Humanities; production conditions warrant research because they help author the text, which has traditionally been the primary subject of study by film scholars. Caldwell also provided a topical approach, presenting quite extensively the impact of new technologies on production and media employees. He first discussed how in addition to producing culture, the industry "leaks culture," which supplies those within Production Studies with research material. This leakage can be done surreptitiously and virally (pertaining to the questions of reflexivity earlier mentioned), but also inadvertently. Caldwell also argued that the current changes create an environment of "stress aesthetics." The new digital technologies spur disorder and contention, which in turn boosts creativity.

6 Creativity as a concept was one of the most significant themes throughout the 2-day conference. There were papers that aimed at theorizing creativity from different 
angles, such as Marja Soila-Wadman's approach from organizational studies, or Eva Novrup Redvall's presentation, "Production Practice as an Interplay between Individuals, the Domain and the Field: A Research Framework for Studying Feature Filmmaking," which discussed how an idea is developed into a film. Similarly, Sara Malou Strandvad followed five film projects over a one-year period, at the end of which all projects ended up in a different stage of production. Other papers often returned to this subject, and the work of creation was discussed in relation to a number of different professions. In addition to the previously mentioned papers on dramaturges and agents, there were a number of case studies investigating transnational workworlds, such as Patrick Vonderau's research on prop makers in present-day Babelsberg Studios. One professional occupation that received considerable attention was scriptwriting. It has been pointed out that this line of work provides researchers with more readily available material in the form of various script drafts. Scriptwriting also has a remarkable relationship with the creative process, bringing into discussion questions of individualism versus working in a community, a topic covered by Bridget Conor in her work on British screenwriters.

7 Individualism was debated largely along with professional positions, as reputations are the key capital owned by all in the field of cultural production. The old Hollywood adage, "you're as good as your last job" was often repeated, yet challenged by the newer "as good as your next idea." Philip Drake's presentation, "'Reputational Capital' and 'Talent Economy': Useful Concepts in Understanding the UK Film Industry?" was for the most part concerned with this issue. At the same time, Drake brought forward another frequently referenced topic, namely the importance of location. Clusters and agglomerations of production have been examined within studies of media industries; they are also inevitably significant to Production Studies. Questioning locality was central to a number of papers. In addition to the historical accounts of runaway productions and collaborations, Isak Thorsen's investigation of runaway productions in contemporary Denmark and Alessandro Jedlowski's analysis of Nigerian video filmmaking in Italy were situated within the existing studies on transnational cinema.

8 All these different approaches demonstrated that there are many possibilities and research questions awaiting to be explored in the field of European Production Studies. This first illuminating and exciting European conference will surely not be the last. With the announcement of the creation of a European Production Studies Network, and the conference proceedings published in 2012, the organizers steered a clear course for establishing this burgeoning field of research in Europe.

\section{AUTEUR}

\section{MELIS BEHLIL}

Kadir Has Universitesi 